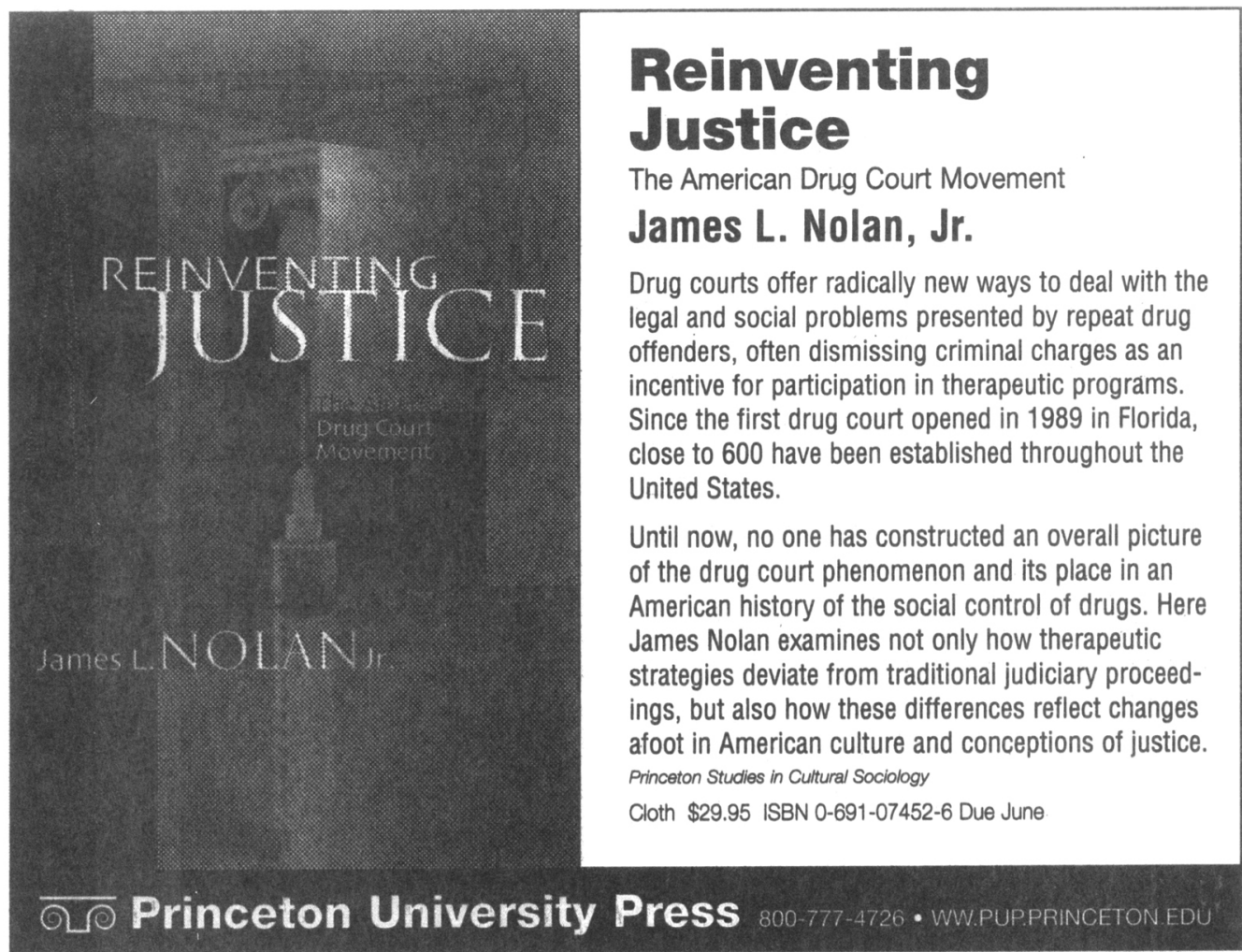

Edited by

Sandra Harding and

Kathryn Norberg,

UCLA
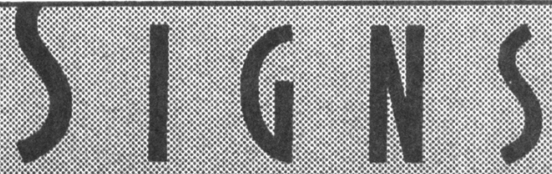

Journal of Women in Culture and Society

The leading international

http://www.journals.uchicago.edu/Signs

journal in women's studies,

Signs has been publishing articles from a wide range of disciplines in a variety of voices for nearly three decades. Now, under its new editorship, Signs seeks to renew debate and discussion with more groundbreaking, provocative articles while staying true to its prestigious reputation. In addition to major essays on gender, race, culture, class, nation, and sexuality, Signs brings to its readers in-depth book reviews, special issues and sections, and "U.S. and International Notes" to provide a forum for lively debate.

Subscribe to Signs to keep current with the latest interdisciplinary research and debate in women's studies.

Published quarterly by The University of Chicago Press. Regular one-year subscription rates: Individuals $\$ 38.00$; Students $\$ 27.00$; NWSA members $\$ 31.00$; Institutions $\$ 140.00$. Outside USA, please add $\$ 6.00$ for postage. Canadian residents, please add postage and $7 \%$ GST. Visa and MasterCard payments are accepted. To order, send check, purchase order, or complete credit card information (acct. \#, exp. date, phone number, and signature) to the address below. Credit card customers may fax their orders to (773) 753-0811 or e-mail them to journal-orders@press.uchicago.edu.

\title{
The University of Chicago Press
}

Journals Division, SF1SA, P.O. Box 37005, Chicago, IL 60637 USA Order online at http://www.journals.uchicago.edu/Signs/ 


\section{LAW AND SOCIETY}

NEW FROM CHICAGO
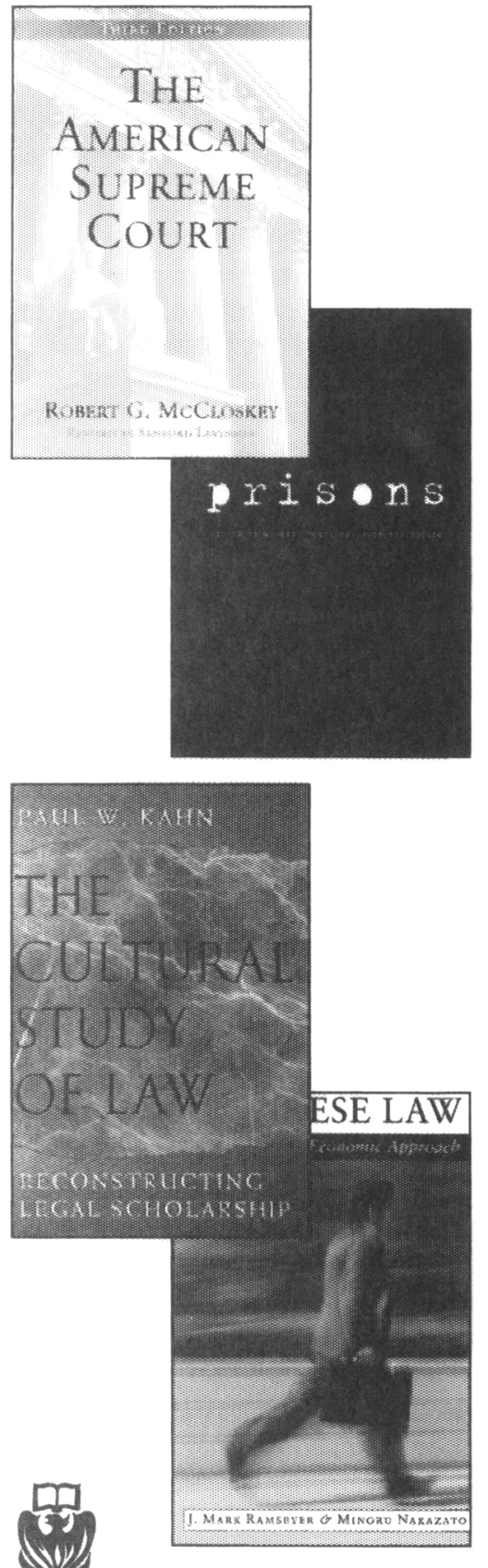

The University of Chicago Press 1427 East 6oth Street, Chicago, IL 60637 www. press.uchicago.edu

\section{The American Supreme Court Robert G. MoCloskey \\ Third Edition \\ Revised by Sanford Levinson}

First published more than four decades ago, Robert MeCloskey's classic work on the Supreme Court's role in constructing the U.S. Constitution has incroduced generations of srudents to the workings of our narions highest court. Sanford Levinson brings this new edition into the wency-first senum revising the lase wo chapress, which cover ree evenws of the past forry years, and updaring the books prefice, coda, chronology, and bibliographical csay.

\section{Tha Cuicaco Mistoery or Ameacan Civizarion PAPER S14.00}

\section{Prisons}

Crime and lustice, Volume 26

Edited by Michael Tony and Joan Petersilla

Prisons provides a compreheasive overviews of policy issues and research developments concerning prisons and imprisonment with chaprers by Alfred Blumstein and Allen Beck, Joan Petersilia, Anthony Botrums. Douglas Midonald, and others.

\section{Paper $\$ 30.00$}

\section{Now in paper}

\section{THE Cultural Studr of Law}

Reconstructing Legal Scholarship

Paul W. Kahn

Thim . . offers the first full examination of what it means so conduct a modern incellecrual inquiry inro the cuiture of law. Charing the way for the development of a new inellocrual discipline, he advocates an approach dhat stands oubside law's normative framework and looks ar law as a way of life rather than a ser of rules."- Kic Liw Repors

\section{PAPEA $\$ 16.00$}

\section{Now in paper}

\section{IAPANESE LAW}

An Economic Approach

\section{Mark Ramseyer and Minoru Nakazato}

"This is a lively and lucid introducrion so lapanese law. 2. For those who are not familiar with cconomic analysis of the law, this book could well be an eye-opeaes. . The authors lave many imeresting and insightful things to say abour the unique features of corporate governance in lapan and abour nergers and takeovers."

- Kecchang Kim, Cimbridgs Law Journal

Srupies in Lw ano Ecowomics Papen $\$ 20.00$ 


\section{The Smart Subscription}

Seize this opportunity to cement your position at the forefront of your field - subscribe to this journal now for $15 \%$ off the regular rate. (See order form on reverse.)

Challenge your ideas with the latest research avallable in each issue. The provocative and discursive content spans the gamut of trends, theories, commentary, and methods of our academic community.

Save $50 \%$ on a complete set of back issues. See order form on reverse, or order online.

\section{The University of Chicago Press http://www.journals.uchicago.edu/}

\section{Law \& Social Inquiry}

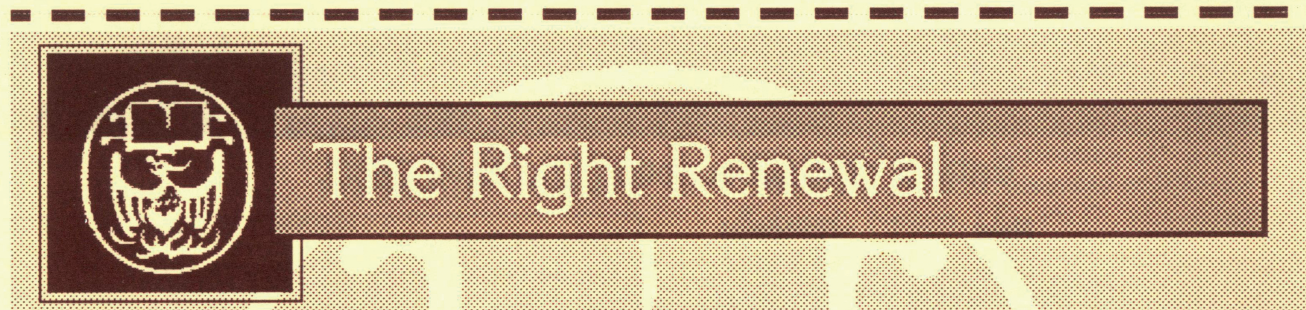

Maintain your position at the forefront of your field with a renewal to this journal. (See order form on reverse.)

Don't interrupt your connection with the latest research avallable in each issue. Recall the provocative and discursive content that spans the gamut of trends, theories, commentary, and methods of our academic community.

Check the mailing label on this issue-your subscription may expire sooner than you think!

Save $50 \%$ on a complete set of back issues. See order form on reverse, or order online.

\section{The University of Chicago Press http://www.journals.uchicago.edu/}

\section{Law \& Social Inquiry}




\section{Law \& Social Inquiry}

Enter a new subscription and save $25 \%$ !

$\begin{array}{lll} & \text { New } & \text { Renewal } \\ \square \text { Individuals } & \square \$ 27.00 & \square \$ 36.00 \\ \square \text { Institutions } & 51.00 & \square 68.00 \\ \square \text { Academics* } & \square 21.75 & \square 29.00\end{array}$

${ }^{*}$ For college/university faculty and students.

Outside USA: please add $\$ 6$ for postage.

Canadian residents: please add 7\% GST.

Back issues: remaining issues (vols. 19-24) at $50 \%$ off (LSI-SET):

$\$ 115.00$ Individuals $\square$ \$207.00 Institutions

Outside USA: please add $75 \propto$ per issue for postage.

Canadian residents: please add $7 \%$ GST.

Payment Options
Fax credit card orders to (773) 753-0811.
$\square$ Charge $\square$ MasterCard $\square$ Visa
Account no. $\square$
Expiration date_
Signature
Phone number (
$\square$ Payment enclosed (U.S. currency only)

Name Phone (_

Address $\operatorname{Fax}($

City/State/Zip/Country E-mail

Visit our Web site at http://www.journals.uchicago.edu/LSI/

For special savings on two and three year rates, please direct inquiries to address listed below.

Please send your order to the University of Chicago Press, Journals Division, P.O. Box 37005, Chicago,

IL 60637 USA.

\section{Law \& Social Inquiry}

Enter a new subscription and save $25 \%$ !

$\begin{array}{lll} & \text { New } & \text { Renewal } \\ \square \text { Individuals } & \square \$ 27.00 & \square \$ 36.00 \\ \square \text { Institutions } & \square 51.00 & \square 68.00 \\ \square \text { Academics }^{*} & \square 21.75 & \square 29.00\end{array}$

*For college/university faculty and students.

Outside USA: please add $\$ 6$ for postage.

Canadian residents: please add $7 \%$ GST.

Back issues: remaining issues (vols. 19-24) at $50 \%$ off (LSI-SET):

$\square \$ 115.00$ Individuals $\square \$ 207.00$ Institutions

Outside USA: please add $75 \varnothing$ per issue for postage.

Canadian residents: please add $7 \%$ GST.

Payment Options
Fax credit card orders to (773) 753-0811.
$\square$ Charge $\square$ MasterCard $\square$ Visa
Account no.
Expiration date__
Signature
Phone number (
$\square$ Payment enclosed (U.S. currency only)

Name Phone (_

Address $\operatorname{Fax}($

City/State/Zip/Country E-mail

Visit our Web site at http://www.journals.uchicago.edu/LSI/

For special savings on two and three year rates, please direct inquiries to address listed below.

Please send your order to the University of Chicago Press, Journals Division, P.O. Box 37005, Chicago, IL 60637 USA. 


\section{American Bar Foundation}

\section{BOARD OF DIRECTORS}

President, Jacqueline Allee, of the Florida Bar • Vice-President, M. Peter Moser, of the Maryland Bar • Secretary, Carrie Menkle-Meadow, Georgetown University Law Center • Treasurer, David E. VanZandt, of the Illinois Bar

James H. Carter, of the New York Bar • Martin D. Ginsburg, of the District of Columbia Bar • Robert O. Hetlage, of the Missouri Bar • Herma Hill Kay, University of California at Berkeley School of Law • Richard Peña, of the Texas Bar • Wilma Pinder, of the California Bar • David K.Y. Tang, of the Washington Bar • Elizabeth Whittenbury, of the California Bar

ex officio:

Martha W. Barnett, President, American Bar Association • Robert E. Hirshorn, President-Elect, American Bar Association • Karen J. Mathis, Chair, House of Delegates, American Bar Association • Earle F. Lasseter, Treasurer, American Bar Association • Charles M. Thompson, President, American Bar Endowment • Zona F. Hostetler, Chair, The Fellows of the American Bar Foundation • Thomas A. Chaney, Vice-Chair, The Fellows of the American Bar Foundation • Steven T. Waether, Secretary, The Fellows of the American Bar Foundation

\section{OFFICERS}

Bryant G. Garth, Director

Joanne Martin, Associate Director

\section{RESEARCH FELLOWS}

Jonathan D. Casper, Ph.D., Yale University

John L. Comaroff, Ph.D., University of London

Stephen Daniels, Ph.D., University of Wisconsin

Shari S. Diamond, Ph.D., Northwestern University; J.D., University of Chicago

Bryant G. Garth, J.D., Stanford University; Ph.D., European University Institute

Austan Goolsbee, Ph.D., Massachusetts Institute of Technology

John Hagan, Ph.D., University of Alberta

Terence C. Halliday, Ph.D., University of Chicago

James J. Heckman, Ph.D., Princeton

Carol A. Heimer, Ph.D., University of Chicago

John P. Heinz, LL.B., Yale University

Bonnie Honig, Ph.D., Johns Hopkins University

Steven D. Levitt, Ph.D., Massachusetts Institute of Technology

Tracey Meares, J.D., University of Chicago
Elizabeth Mertz, J.D., Northwestern University; Ph.D., Duke University

Janice Nadler, J.D., University of California at Berkeley; Ph.D., University of Illinois

Robert L. Nelson, J.D., Ph.D., Northwestern University

Laura Beth Nielsen, J.D., Ph.D., University of California at Berkeley

William Novak, Ph.D., Branders University

Annelise Riles, Ph.D., University of Cambridge;

J.D. Harvard University

Mary R. Rose, Ph.D., Duke University

Robert J. Sampson, Ph.D., State University of New York at Albany

Susan P. Shapiro, Ph.D., Yale University

Christopher L. Tomlins, Ph.D., Johns Hopkins

Victoria Saker Woeste, Ph.D., University of California, Berkeley

\section{LIAISON RESEARCH SERVICES PROGRAM}

Joanne Martin, M. M. Northwestern University, J.D. Loyola University

Barbara A. Curran, LL.B. University of Connecticut, LL.M. Yale University 


\section{Law \& Social Inquiry}

\section{Volume 26, Number 2, Spring 2001}

SYMPOSIUM: Colonialism, Culture, and the Law

Colonialism, Culture, and the Law: A Foreword JOHN L. COMAROFF

The Legal Cartography of Colonization, the Legal Polyphony of

Settlement: English Intrusions on the American Mainland in the

Seventeenth Century CHRISTOPHER TOMLINS

Making Order Out of Trouble: Jurisdictional Politics in the Spanish Colonial Borderlands LAUREN BENTON

Bureaucrats and Indians in a Contemporary Colonial Encounter WENDY NELSON ESPELAND

Colonialism's Civilizing Mission: The Case of the Indian Hemp Drug

Commission RONEN SHAMIR AND DAPHNA HACKER

\section{REVIEW ESSAYS}

What's Law Got to Do with It? Judicial Behavioralists Test the "Legal Model" of Judicial Decision Making HOWARD GILLMAN

Moving beyond the Child Support Revolution ANN LAQUER ESTIN

Strategies of Constitutional Scholarship ERIC A. POSNER

\section{BOOK NOTES}

